\title{
O YOU HAVE ANY EMPTIES?"
Bottle Collectors' Interactions in
Public Spaces in Zagreb
}

Dino Vukušić

Zagreb

\section{Stephanie Stelko}

Zagreb

\begin{abstract}
This paper describes the practices of people who collect discarded bottles and cans during public events in Zagreb, Croatia, which they return to recycling centers in order to receive a bottle deposit needed to supplement their low incomes. In addition to an ethnographic section in which we briefly describe this underrepresented aspect of everyday life in Zagreb, we address the symbolics at play in bottle collectors' interactions among themselves and with "bottle providers" - people who gather in public spaces and consume drinks from bottles and cans. In so doing, we describe how the presence of a marginalized social group becomes visible in public spaces.
\end{abstract}

Keywords: bottle collecting, marginalized groups, symbolics of interaction, public spaces, Zagreb

\section{The "Bottle Economy" in Croatia}
"Can I take this bottle?" a middle-aged woman holding a trash bag full of empty bottles and cans asks, as she takes an empty plastic bottle lying by the bench.
"Yes, sure", our friend replies, sitting on the bench.
"What about that one?" the woman asks, pointing with her finger at a bottle of wine.
"That one's still full”, our friend says, shrugging as if she were apologizing, and the woman withdraws, proceeding her search elsewhere.

It was a Friday evening in June, when students of the Faculty of Humanities and Social Sciences in Zagreb were enjoying their traditional end-of-year party. We were sitting on a bench not far from the Faculty building along with some friends, surrounded by many other young people who had gathered in the same area, listening to live music and having drinks. In addition to the students, among the crowd we noted at least nine people moving around, holding plastic bags and looking for empty bottles and cans in and around the trash bins, by the benches and elsewhere. The presence of bottle collectors at this event did not surprise us at all. On the contrary, we were expecting them. Bottle collectors have been present at every outdoor party or public event that we have attended over the last eight years of going to such events in Zagreb. We knew that they would come, and they also knew that we - students, young people, bottles and cans - would be there that evening.

In 2006, the Republic of Croatia became one of the countries which implemented container-deposit legislation (CDL). Many countries around the world have a form of CDL, most often implemented for environmental purposes. Th is was also the case in Croatia, where the programme was initially organised by the Ministry of Environmental and Nature 
Protection. According to the Croatian CDL, market producers of drinks packed in PET or aluminium/iron pay a fee to the Environmental Protection and Energy Efficiency Fund. The end users, or consumers, may return these bottles and cans to recycling centers or sellers in order to obtain a refund, and recycling centers/sellers then receive a refund from the Fund. ${ }^{1}$ The bottles and cans may be returned to supermarkets in exchange for a refund of 0.5 kunas per unit, ${ }^{2}$ either being left with supermarket employees or being deposited in reverse vending machines in exchange for cash. Shortly after the law was implemented, it became clear that the returning of these items had become a social issue. The journey from increasing ecological awareness to surviving another month in the Croatian economic reality was short.

After entering a period of recession in 2008, Croatia has struggled to overcome numerous difficulties, both economic and concerning living standards in general. In 2008 the whole world was hit by an economic crisis, which represented a severe attack on the weak Croatian economy, which was still suffering from the consequences of the transition during the 1990s. After Croatia gained independence in 1991 and the new political elites carried out a process of privatization in a non-transparent manner, transition-related problems and insecurities emerged (Grubiša 2010: 77). Coupled with the 2008 recession, this situation resulted in high unemployment rates (specifically $21 \%$ in the capital city of Zagreb, in 2013) and low pensions for retired people. ${ }^{3}$ Many were forced to search for "alternative" ways of earning - the so called "gray zone" or "informal economy" (Rubić 2013). This resulted in cash payments without any social insurance included, such as medical insurance or pension contributions, becoming an everyday reality for many Croatian workers. As Štulhofer (2000) pointed out, some people became "transition losers" and these are in fact the people who have suffered the most over the last twenty-five years of changes which have taken place in Croatian society. Under such circumstances, it is no surprise that bottle collecting to reclaim the deposit became a widespread "alternative" method of earning, a method also used in economically more powerful and stable countries, such as the United States of America or Germany (see Whittle 2012; Mayyasi 2013).

Despite some government ministers having reconsidered the whole project, mostly because of certain irregularities ${ }^{4}$ as a result of which the Croatian state budget was damaged by 700 million kunas, ${ }^{5}$ as the media have reported, ${ }^{6}$ the practice continues, and many "bottle collectors", 7 as people tend to call them, can still be frequently seen on streets, squares and parks all over Croatia. Their practices of collecting, interacting among themselves and with other people, combined with their general "being in the city" represent a very complex, yet underrepresented phenomenon in social studies of urban livelihood. Thus, this article will address one segment of bottle collectors' "being in public spaces", outlining their contribution to urban public spaces in Zagreb.

We were unable to find any anthropological studies of discarded bottle collecting, but stories written by investigative journalists show that bottle collecting has been recognized as

\footnotetext{
${ }^{1}$ Article 22, "Pravilnik o ambalaži i otpadnoj ambalaži" ["Regulations regarding packaging and waste packaging"] by the Ministry of Environmental and Nature Protection (http://narodne-novine.nn.hr/clanci/sluzbeni/2015_08_88_1735.html, accessed 3. 6. 2016).

${ }^{2}$ Appoximately 0.07 euros.

${ }^{3}$ According to data available on the Croatian Employment Service web-site (http://trzisterada.hzz.hr/, accessed 11. 7. 2016).

${ }^{4}$ For example, the codes written on containers were the same in Slovenia and Croatia, so people would come from Slovenia to obtain their refund, even when the products were not bought in Croatia.

${ }^{5}$ Approximately 93,480,465 euros.

${ }^{6}$ For example: Jutarnji list on 3 December 2010 (Malić 2010).

${ }^{7}$ Since this term is most often used among people in Zagreb, we will use it here too in order to refer to people who collect discarded plastic or glass bottles and cans. For the same reason, we will also refer to their activity as "bottle collecting", although they also collect cans.
} 
a social issue elsewhere, such as in Berlin (Whittle 2012) and San Francisco (Mayyasi 2013). In these cities people supplement or gain their primary income through collecting discarded bottles. These articles report the presence of a large amount of competition among people who collect bottles, not only during daytime hours, but also in the evening when (young) people gather in public spaces such as parks and consume drinks, thus using up many bottles. Indeed, we have made similar observations in Zagreb: there are people who collect bottles daily and those who only attend public happenings such as gatherings of young people, open-air concerts and other events where a large number of people spend time outside whilst drinking from bottles and cans. Furthermore, bottle collecting may represent a person's only way of earning a living, while others do it in order to supplement their low pensions or salaries. Some spend most of the money earned through bottle collecting on alcohol. They may often be seen "hanging around" and drinking alcohol in front of the supermarket at which they returned the collected bottles, sometimes together with other collectors. As the "bottle collecting scene" in Zagreb is a very complex phenomenon, the description of which exceeds the scope of this paper, here we focus on people who only collect bottles occasionally in order to supplement their income. In other words, this paper addresses people who only collect bottles during public events in a sober state.

\section{Theoretical Inspiration and Research Process}

The "pioneers" of qualitative urban sociology, best known as the Chicago School of urban sociology, focused their work around certain aspects of "street events" in Chicago during the 1920's, showing how the dynamism of events in urban contexts constructs both individual and group identities (Čaldarović 2012: 8). They used Chicago as a "social lab" through which they accumulated stories trying to analyze "deviant" aspects of living in a rapidly growing city (ibid.: 13). Making use of qualitative methods, they wrote a larger number of monographs based on extended observations over many years of "marginal" or "deviant" groups (ibid.: 8). Inspired by the Chicago School's fascination with "marginal" groups in an urban context, in this paper we address an underresearched and, as we argue, generally "marginal" group in Zagreb.

According to the Oxford Dictionary, marginalized people, groups or concepts are those that are considered to be insignificant or peripheral. ${ }^{8}$ In social sciences, marginalized people are usually seen as vulnerable (see for example Van der Aa et al. 2009; Flicker et al. 2007). We believe that bottle collectors fit the definition of a marginal social group for several reasons. First, they are economically vulnerable, and the fact that they need to spend a lot of time outdoors, sometimes at night, contributes to their vulnerability. Second, the underrepresentation of bottle collectors in public discourses creates the impression that the public does not pay much attention to them. Moreover, although bottle collectors spend much of their time on the streets and are thus publicly exposed on a daily basis, people who pass by only notice them with their "peripheral vision", to use an appropriate metaphor. Finally, certain bottle collectors are especially vulnerable owing to their gender, age, physical or mental health, and other characteristics.

Yet, in this paper we argue that in certain moments these people do become more visible by entering into more direct interactions with other inhabitants of the city, especially during

${ }^{8} \mathrm{http}: / /$ www.oxforddictionaries.com/definition/english/marginalize (accessed 11.7.2016). 
public events. These interactions may be analyzed as symbolic acts, subject to interpretation within the social context. Approaches based on theories of symbolic interactionism focus on thinking, action and interaction, decision-making processes, the acquisition of meanings, and the meaning of symbols (Ritzer 1997: 179). Applying this approach, we focus on research into a marginalized group in an urban context, through analyzing the symbolics at play in bottle collectors' interactions among themselves and with other people. In addition to this explanatory part, this paper also presents a description of bottle collectors' "being in public space" in an urban context, thus aiming to contribute to a better understanding of everyday "socio-spacial" dynamics in Zagreb.

The idea for this research emerged from extended observations of bo the collection over many years, during which the authors participated in numerous public events in Zagreb. This research also draws on insights gained through occasional chats with people who collect bottles. The official fieldwork, on the basis of which the main information and observations presented in this article were gathered, took place in June and July 2016. A thorough study of the "bottle collecting scene" in Zagreb may result in the production of a complex typology, including vast descriptions of different people's everyday practices. As this fieldwork - with its several limitations - is one of the first attempts to scratch the surface of this "scene", we have decided to focus on one aspect in which the phenomenon under study is the most visible and accessible: we have therefore conducted our fieldwork during public events.

As pointed out by Handleman (1998: 9), "events are important phenomena because they constitute dense concentrations of symbols and their associations". During public events, he further explains, cultural codes - usually diffused and submerged - "lie closest to the behavioral surface" and become "most graspable in various sensory and cognitive modalities" both by natives and ethnographers (ibid.). Indeed, in our case public events turned out to be a frutiful source in many ways.

During June and July 2016, we attended several public events, mostly concerts, held at different locations in Zagreb. A music festival took place at King Tomislav Square in the city center and many people attended the festival concerts, sitting on the grass and drinking from bottles recently purchased in the nearby shops. Other events which we attended as participant observers included the Open Air Festival organized by students of the Faculty of Humanities and Social Sciences in front of the Faculty building on the last day of classes near the end of the academic year, and a gathering of people prior to a concert in a hall at Zagrebackki Velesajam, ${ }^{9}$ with people gathering in the public spaces around the hall.

On these occasions, lots of people gathered in a relatively limited area - a square, a park, a parking lot - bringing bottles and cans with them and using them up as time went by. A dense concentration of "bottle providers" and therefore bottles a ttracted a lot of people who came to collect them, and thus their concentration became higher than in "regular" circumstances. Furthermore, their interaction with one other and with the "providers" came to the surface and was consequently more easily observable and more spontaneously discussed, as participants in public events often tended to comment on the phenomenon of bottle collecting, and - as we describe later - bottle collectors approached "providers" and occasionally made comments themselves. For us as ethnographers, in Handleman's (1998: 9) terms, public events were "privileged points of penetration into other social and cultural universes".

Even though this phenomenon was more readily approached during public events, we still encountered several barriers when trying to interview bottle collectors and have thus

\footnotetext{
${ }^{9}$ A complex of buildings in Novi Zagreb ("New Zagreb", part of the city built in the 1960s, when Zagreb spread across the Sava river), where a flea market was initially held, but which is now used for several events such as concerts, sports, book fairs etc.
} 
considered questions of a methodological and ethical nature throughout the entire research process. The first barrier relates to the fact that people who collect bottles can only be identified as such when they are collecting bottles - and in these moments they are often unwilling to spend time talking, as they want to collect as many bottles as possible. Second, in some cases we did not feel comfortable approaching some potential informants, since they appeared to be under the influence of alcohol, or to have mental health problems. On the other hand, many people that we did try to approach were not willing to talk to us, presumably because they felt embarrassed or humiliated. Finally, those who did talk to us only agreed to a short conversation and rejected exchanging contacts and meeting us in other settings for an interview. We are also aware of the fact that our rapport with bottle collectors was additionally affected by the fact that we were in a privileged position in relation to them, as often we assumed the role of "bottle providers" - collectors would approach us to take our empty bottles, engaging in brief communication with us. These instances represent the moments in which our observations became "participant": we engaged in the process of bottle collection, assuming the role of "providers".

Participant observation - namely naturalistic participant observation, carried out in "natural" settings - turned out to be our most fruitful research tool. Since the observations took place in public spaces during events held for the public, our participant observation was covert in many instances and thus we need to significantly consider the ethical aspects of our approach.

As discussed by Li (2008), covert participant observation has been a subject of "controversy and debate on research ethics, mainly regarding the deception and the absence of informed consent from the people being studied" ( $\mathrm{Li} 2008$ : 101 and there mentioned authors). Yet, as covert participant observation is "more likely to provide detailed portraits of contextualized social realities", many researchers continue to employ this method, especially those who aim to represent disadvantaged groups (ibid.). As Li put it, social scientists should not only uncover and interpret people's voices, but also understand their silence (ibid.: 112), and in some cases, covert observation might be the only way to achieve this.

Furthermore, Spicker (2007: 3) argues that "there are contexts in which it is neither feasible nor desirable to obtain voluntary consent from the people being studied", and lists observation of crowds among other examples of such contexts, as obtaining consent from everyone observed would represent a big obstacle to the research being done at all.

According to Spicker (2007:2), privacy relates to the personal and private spheres of life, while much of social life is neither personal nor private. Public settings limit individuals' right to privacy and objects of social scientific inquiry can become embedded in public settings, thus being something that can be publicly observed (ibid.).

Returning to our fieldwork, we strived to avoid concealment as much as possible and none of the interviews or short conversations were carried out without us informing the person of our intentions, nor without the person's consent being obtained beforehand. As most of our observations were carried out in crowds, and since the people who collect bottles that we did not interview were present in these crowds, we were not able to obtain informed consent from every observed individual. Yet, during both the research and writing process we followed ethical principles commonly used in anthopology, taking care that our observations would not harm any of the persons included in this study. Moreover, none of the descriptions and information presented in this article will in any way disclose the identities of any of the observed people, or of those people who we interviewed.

In addition to participant observation and short interviews with people who collect bottles, we interviewed five people who often attend public events, and who have been in con- 
tact with people who collect bottles on several occasions. Their names have been changed in order to protect their identities as well. Finally, some of the insights relating to the "bottle provider" point of view are based on our own participation and reflections. Thus, it is important to note that everyone involved in this study - the authors, the interviewed bottle collectors and the "bottle providers" - have all acted as observers of the phenomena reported in this paper, and have also been simultaneously observed by other stakeholders in the study.

\section{"Could You Save Your Bottles for Me?" Competition and Compassion during Public Events}

A couple of hours before the event - usually a concert - begins, public spaces in Zagreb start to transform into a venue frequented by groups, even masses of people. Many use nearby supermarkets to buy drinks and then occupy a certain place in front of the stage. Initially sitting in smaller groups, they "warm up" for the event by chatting as they consume their drinks. As the beginning of the concert approaches, public spaces become ever more crowded and isolated groups now become a part of a bigger mass. Groups in this mass remain divided by small "paths" between circles of bodies formed by people standing or sitting around. These "paths" become "routes" for the bottle collectors who walk around looking for empty, or in some cases half- or nearly empty bottles. Some of them simply walk around, while others engage in short conversations with people after asking them whether or not they have "something empty", as they tend to say. After the evening program reaches its peak, some of the crowd heads off to other events or places, while those who stay often renew their drink supply by visiting supermarkets that work late at night. As for the bottle collectors, some of them also leave along with the mass, while the "more determined" ones continue cruising around or just sitting in the area, hoping that they can still "catch something".

During our observations, we noted that people who collect bottles are generally old, although in a few instances we observed middle-aged or younger persons. Our impression was that there were more male bottle collectors than female, although there were many women, and in fact we found women to be more easily approachable, and eventually conducted more interviews with female collectors than male, as will be discussed later in the article. The visual expression of bottle collectors encompasses a very simple style of dress and several plastic bags in their hands. However, some differences may be noted as concerns bottle collectors' visual expression - in clothing, hairstyle, body language - which might be conformist, or more unusual on occasion.

The number of people who a tend public events in Zagreb in order to collect bottles is striking, and so we could not help but wonder how all these people found out that a specific event worth visiting was going to take place, especially as concerns events happening outside of the city center, which meant that these people came to the relevant location on purpose. Following a few conversations, we found out that the media were the main means through which information was gathered. A bottle collector in front of the Zagrebački Velesajam told us that he followed events in Zagreb on the Internet, while an older woman at King Tomislav Square said that she typically found out about public events through the radio or television and would then suppose that there might be bottles to collect.

As more and more people are forced to turn to bottle collecting, they inevitably come into contact with one another, in so doing developing opinions about each other. They have 
their own criteria for differentiating themselves from other "types" of collectors. Being aware that bottle collecting might be perceived by some as a "job" beneath human dignity, our informants' narratives reflect their wish to "re-establish" themselves as honest citizens. By contrasting themselves with the "other ones" - "crazy", "drunk" or "aggressive" - they aim to prove themselves as being "normal".

During a conversation that took place at King Tomislav Square, when describing her process of collection, Marija emphasized that she is not like "those who drink", giving the example of a man who "falls down between people" and persistently "annoys" people to give him bottles. During the Open Air Festival, Branka, who claimed to occasionally give the bottle refund to her old neighbor, told us that there is a man who collects daily in the city quarter where the Faculty is based and who acts "as if the quarter was just his". When asked if she had ever found herself in any unpleasant situation whilst collecting, Sofija told us that she "stays out of trouble" because she only comes to events and does not "go around digging in the trash" as some people do.

One evening at King Tomislav Square there were indeed a lot of people collecting bottles and even at first glance the competition among them seemed to be high. While we were sitting on the grass having drinks, someone would approach us every few minutes, asking whether we had any available bottles. At one point, a woman in her early sixties approached us lamenting loudly. Đurđa was holding a plastic bag with only a few bottles in her hand and bitterly told us that "that woman over there is just sitting on a bench and everyone is bringing her bottles because she is old and has a walking stick", while Đurđa had walked "miles and miles" that night on a foot recovering from surgery, but had been unsuccessful because her pain was not explicitly visible. When interacting with us, not only did she employ the technique of direct approach, but she also tried to provoke our compassion, as we will further argue later. She showed us her almost empty plastic bag and rolled up her trouser leg to make us see her slightly swollen, hurting leg. "I've got three grandchildren", she added sighing. As we did not have any empty bottles to give her at that moment, she imploringly asked us to save our bottles for her.

The woman she complained about, Sofija, approached us twice that evening. During a conversation we had with her, she told us that her experiences with people from whom she takes bottles have mostly been pleasant. Somewhat earlier that evening, she told us, some girls had been collecting bottles and bringing them to her in order to help her, since she found it hard to walk and collect bottles while supporting herself with a walking stick.

The interactions between bo the collectors and "providers" range from being completely impersonal to repeated enagagement in more intensive forms of interaction. When circulating between groups of people attending a public happening, bottle collectors "scan" their bottles to gauge whether they are available or not. When they find a bottle that might be collected, they pursue a variety of strategies. As Zoran - a young man who often attends these kinds of events and who has been in contact with bottle collectors on many occasions - told us, some people politely ask whether a bottle is "free", while others will just move up close and take a bottle without saying anything. While Zoran attributes their choice of approach to their level of politeness, we also observed that some people seem to try to be as unobtrusive, or even as invisible as possible, while others have no problems with initiating direct contact with "bottle providers".

Both Zoran and Tomo - another young man who often attends public gatherings and who has been in contact with bottle collectors on many occasions - reported, after having participated in such events for a while, they have started to recognize certain bottle collectors 
who they would often come across, and over the course of time their interactions with these collectors have intensified. Zoran told us about a bottle collector who used to spend some time with him and his friends, who even gave him a nickname. When asked to explain his perception of this man, Zoran told us that he sees him as a "normal elderly man" who satisfies his needs for social interaction by spending time with young people and earning some money while doing so. He also reported being aware of bottle collectors during bigger public happenings and claimed that he prefers to give his bottles to collectors that he finds more polite.

Silvia, on the other hand, reported having very impersonal forms of contact with bottle collectors: "They don't change [what I do when I go out], except that I give them bottles or cans instead of throwing them away in a bin", she told us, adding that she interacts with bottle collectors only when "I tell them that I'm still drinking [from that bottle] or that they may take it, because it's empty".

When asked whether bottle collectors' presence impacts on his experiences spent in public spaces in any way, Tomo told us that generally he does not even think about them when he goes out, but that:

sometimes when they come they annoy me a bit because they ask whether there's something [a bottle] empty, and the worst is when some of my friends say: "come on, drink up so we can give it to the woman". That gets on my nerves a bit because I came [to the public event in question] to have my beer in peace. Normally, when I have an empty bottle, I give it to them or tell them where I've left it but usually I don't have any further contact with them. That's more or less all the interaction [that I have with them]. And I'm annoyed by those ones that first ask about the bottles and then start talking, I think they are looking for someone to have a conversation with and then they just keep on going.

Tomo also told us that he usually does not "save" his bottles for a specific collector. "Generally, when I have an empty bottle, first come, first served", he explained.

Even though they may have very impersonal relationships with bottle collectors, we have noted that the presence of collectors changes their practice of dealing with garbage bins. During public events, many bottles and cans may be observed being left around trash bins, on the bins' covers or in the ashtrays which are present on or near the top of some bins. "I feel bad when people need to dig in the trash", Zoran explained as his reason for leaving bottles beside the trash can. Such actions and narratives indicate that people who attend public happenings are aware of the existence of bottle collectors in the space and that this awareness impacts on their practices.

Finally, we encountered an interesting example of an interaction between a bottle collector and "bottle providers" which took place when entering a concert hall at the Zagrebački Velesajam. Before the concert, many people had gathered around the Velesajam to have drinks with friends who were also going to the concert. When the concert hall opened its gates, people rushed in, but needed to pass through a security check at the entrance. As usual, the process encompassed a ticket check and the checking of bags for dangerous objects - or bottles. ${ }^{10}$ Interestingly enough, in addition to putting the bottles in trash bags that were hanging by the entrance, visitors could hand their bottles to a man who was standing in front of the ticket checking area. Indeed, the trash bags were almost empty, while several completely full bags were lying on the floor behind the man. The security personel were cha thing with him and allowing people to return from the bag checking area in order to give him their bottles.

\footnotetext{
${ }^{10}$ Taking bottles into the concert hall is not permitted because concert organizers want to ensure that people will purchase drinks at the bars inside the concert hall.
} 


\section{Bottle Collectors' Techniques and Tactics: A Symbolic Interactionist View}

As argued above, public events represent moments of intensified reality, while also being constituted of everyday practices of exchange. When it comes to the bottle collecting "scene", the specifics of public events make themselves manifest in two ways. First, as we explained earlier, spaces where public events are organized have their own "life" on "ordinary" days. This means that certain groups of people spend their evenings there every week and that certain bottle collectors are repeatedly active in that area. Typically, quite a small number of collectors "operate" in one area and as time goes by they get to know each other, and the other people who spend time there. As reported by Branka, these collectors sometimes act as if they have a monopoly on bottle collecting in a specific area. During public happenings, as the number of bottle "providers" suddenly becomes much bigger, a larger number of collectors gain "pretensions" over the same territory and they also go and collect there, circumventing the usual practice.

Second, their usual practices are changed by the fact that bottle collectors, often perceived as "marginal Others", become visible actors. Their visibility emerges from their high concentration, and implicitly from the fact that their contact with other people is intensified.

In line with theories of symbolic interactionism, here we turn to the symbolic dimension of these interactions. As explained by Goffman (1959: 1), one of the key authors who developed this approach, when people meet they create opinions about the other by interpreting some of their visible characteristics, which Goffman calls "sign-vehicles". "If unacquainted with the individual", he further claims, "observers can glean clues from his conduct and appearance which allow them to apply their previous experience with individuals roughly similar to the one before them or, more important, to apply untested stereotypes to him" (ibid.). In the case of the bottle collector-bottle provider interaction, these stereotypes may often be built upon a picture of bottle collectors as, for example, drunk and potentially aggressive or annoying, as we have argued earlier.

Being apparently aware of the existence of such stereotypes, the bottle collectors that we talked to distanced themselves from "problematic" collectors in their narratives. They did so under their own initiative - not being explicitly asked by us - quite early during our conversations. We believe that by doing so, they have tried to "manage our impressions" about them (ibid.: 208) and present themselves as "fair" persons who have not "lost their dignity", as they do not "dig through trash bins", drink too much alcohol or enter into conflict with other people. This might not only be a way of managing our impressions, but also their "spoiled identity" (Goffman 1986). "I never imagined that I would end up doing this”, Sofija told us, and continued her narrative by emphasizing reasons why what she does is still not "that bad".

The practice pursued by many collectors of approaching groups of people very unobtrusively, as well as choosing not to speak with us as researchers, constitutes another technique used to manage "spoiled identities". We believe that unobtrusiveness and striving to be "invisible" represents a way of coping with feelings such as shame and disappointment.

Returning to impression management, certain techniques are employed by bottle collectors as a means of improving their effectiveness in a competitive environment. It seemed that Đurđa, for example, who approached us lamenting about her life situation and the other collectors, aimed to make us feel pity. She wanted to convince us that she too - with her aflicted foot and three grandchildren - is in need just as much as some of the other collectors. 
Đurda's lamentations about the small number of bottles she managed to collect because of the presence of other collectors indicates that the demand for discarded bottles is bigger than its "supply". Usually, bottles are collected according to the principle "first come, first served", but we argue that on certain occasions "providers" perform a sort of triage. While the term triage is most often used in connection with medical emergencies at present, its original meaning, according to the Oxford Dictionary, refers to "the action of sorting items according to quality". ${ }^{11}$ In our case, based on the compassion inculcated towards a specific collector, or based on their perception of collectors' needs, they may choose whom to save their bottle for. On the basis of the reports made by our informants, we argue that "providers" generate their opinions based on collectors' visual expression and manners - the available "sign vehicles". The collectors' bodies represent symbols that are interpreted by providers as more or less worthy of compassion.

We are aware that our selection of informants was influenced to a certain extent by similar cognitive processes. On a pre-conscious level, for us, older women seemed more easily approachable and more pleasant to talk to. The fact that some of them started talking to us on their own initiative indicated their willingness to initiate contact with us, although this might have been their way of attempting to trigger our sympathy towards them so they could obtain our bottles.

In describing their techniques, we want to argue that at public events these people "leave" their marginal position behind and become more visible - either through direct interaction with bottle "providers", or indirectly as "providers" no matter what their attitudes towards collectors are, having demonstrated an awareness of their presence in public spaces.

In our opinion, bottle collectors may be considered an "impacting factor" which through their physical presence in space, the symbolics of their bodies, presence and practices - alters the total social reality of public events to a certain extent.

This paper represents just one small contribution to better understanding an unresearched bottle collecting "scene" in Zagreb. As we have only addressed one aspect of this "scene", there is still a great deal of space for further research that would offer more insights into this phenomenon. For example, the insights presented in this paper would be nicely complemented by research focused on daily collectors "operating" in specific neighbourhoods throughout Zagreb, as well as situating this phenomenon in the wider economic and political context through conducting an analysis of bottle collectors' life stories.

\section{REFERENCES}

Croatian Employment Service. "Labor Market Indicators". http://trzisterada.hzz.hr/ (accessed 11. 7. 2016).

Čaldarović, Ognjen. 2011. Urbano društvo na početku 21.stoljeća. Zagreb: Jesenski i Turk - Hrvatsko sociološko društvo.

Čaldarović, Ognjen. 2012. Čikaška škola urbane sociologije. Zagreb: Jesenski i Turk -Hrvatsko sociološko društvo.

Flicker, Sarah, Robb Travers, Adrian Guta, Sean McDonald and Aileen Meagher. 2007. "Ethical Dilemmas in Community-based Participatory Research. Recommendations for Institutional Review Boards”. Journal of Urban Health 84/4: 478-493. https:// virtualtour.wlu.ca/documents/33344/JUH_CBR_Ethics.pdf (accessed 9.7.2016).

Goffman, Erving. 1959. The Presentation of Self in Everyday Life. Garden City, N.Y.: Doubleday.

Goffman, Erving. 1986. Stigma. Notes on the Management of Spoiled Identity. New York: Touchsstone Book.

Grubiša, Damir. 2010. "Anti-corruption Policy in Croatia. Benchmark for EU Accession”. Politička misao 47/5: 69-95. http://hrcak. srce.hr/index.php?show=clanak\&id_clanak_jezik=102664 (accessed 4. 6. 2016).

Handelman, Don. 1998. Models and Mirrors. Towards an Anthropology of Public Events. New York - Oxford: Berghahn Books.

Li, Jun. 2008. "Ethical Challenges in Participant Observation. A Reflection on Ethnographic Fieldwork". The Qualitative Report 13/1: 100-115. http://nsuworks.nova.edu/cgi/viewcontent.cgi?article=1608\&context=tqr (accessed 9. 7. 2016).

\footnotetext{
${ }^{11} \mathrm{http}: / /$ www.oxforddictionaries.com/definition/english/triage (accessed 10. 7. 2016).
} 
Malić, Goran. 2010. “Afera deset puta teža od Fimi-Medije: Mladineo, gdje je nestalo 700 milijuna kuna?”. Jutarnji list (online), 3. 12., http://www.jutarnji.hr/vijesti/hrvatska/afera-deset-puta-teza-od-fimi-medije-mladineo-gdje-je-nestalo-700-milijunakuna/1894533/ (accessed 2. 6. 2016).

Mayyasi, Alex. 2013. "Making a Living Collecting Cans". Priceonomics (online), 8. 10., http://priceonomics.com/making-a-livingcollecting-cans/ (accessed 2. 6.2016).

Ministry of Envirnomental and Nature Protection of the Republic of Croatia. 2015. "Pravilnik o ambalaži otpadnoj ambalaži” ["Regulations regarding packaging and waste packaging”]. http://narodne-novine.nn.hr/clanci/sluzbeni/2015_08_88_1735.html (accessed 3. 6. 2016).

Oxford Dictionary. “Triage”. http://www.oxforddictionaries.com/definition/english/triage (accessed 10. 7. 2016).

Oxford Dictionary. "Marginalize". http://www.oxforddictionaries.com/definition/english/marginalize (accessed 11. 7. 2016).

Ritzer, George. 1997. Suvremena sociologijska teorija. Zagreb: Nakladni zavod Globus.

Rubić, Tihana. 2013. “Ja se snađem'. Neformalna ekonomija i formalna nezaposlenost u Hrvatskoj”. In Hrvatska svakodnevica. Etnografije vremena i prostora. Jasna Čapo and Valentina Gulin Zrnić, eds. Zagreb: Institut za etnologiju i folkloristiku, 65-90.

Spicker, Paul. 2007. "Research without Consent". Social Research Update 51: 1-4. http://citeseerx.ist.psu.edu/viewdoc/download? doi=10.1.1.224.6256\&rep=rep1\&type=pdf (accessed 9.7.2016).

Štulhofer, Aleksandar. 2000. Nevidljiva ruka tranzicije. Ogledi iz ekonomske sociologije. Zagreb: Hrvatsko sociološko društvo.

Van der Aa, Niels, Geertjan Overbeek, Rutger C. M. E. Engels, Ron H. J. Scholte, Gert-Jan Meerkerk and Regina J. J. M. Van den Eijnden. 2008. "Daily and Compulsive Internet Use and Well-Being in Adolescence. A Diathesis-Stress Model Based on Big Five Personality Traits". Journal of Youth and Adolescence 38/6: 765-776. http://link.springer.com/article/10.1007/s10964008-9298-3 (accessed 9. 7.2016).

Whittle, Helen. 2012. "Increasing Returns. Berlin's Poor Collect Bottles to Make Ends Meet". Spiegel Online International, 23. 3., http://www.spiegel.de/international/germany/pensioners-inberlin-collecting-sit-bottles-to-supplement-income-a-823409. html (accessed 2. 6. 2016).

\section{“Imate nešto prazno?" Interakcije skupljača boca u zagrebačkim javnim prostorima}

\section{Sažetak}

U ovom se radu opisuju prakse osoba koje skupljaju odbačene boce i limenke tijekom javnih događanja u Zagrebu, koje potom vraćaju u centre za recikliranje u kojima dobivaju naknadu za povrat kojom ostvaruju dodatni prihod kao nadopunu svojim niskim primanjima. Osim etnografskog dijela u kojemu ukratko opisujemo taj aspekt svakodnevnog života u Zagrebu o kojemu se vrlo malo govori, bavimo se i simbolikom interakcije skupljača boca među sobom is "davateljima boca", odnosno osobama koje se okupljaju u javnom prostoru i konzumiraju pića iz boca i limenki. Tako opisujemo način na koji prisutnost marginalizirane društvene skupine postaje vidljiva u javnom prostoru.

Ključne riječi: skupljanje boca, marginalizirane skupine, simbolike interakcije, javni prostori, Zagreb 